\title{
EFFECT OF DEXEMEDITOMEDINE AND PROPOFOL ON THE PREVENTION OF EMERGENCE AGITATION FOLLOWING SEVOFLURANE ANESTHESIA IN EGYPTIAN CHILDREN
}

\section{By}

\author{
MOFEED ABDALLA ABDEL-MA'BOUD \\ Department of Anesthesia and ICU, Faculty of Medicine, Al-Azhar University, \\ Nasr City, Cairo, Egypt \\ Abstract
}

This study evaluated the effect of dexemeditomedine and propofol on the prevention of emergence agitation following sevoflurane anesthesia in children. Sixty children, aged 4-6 years, ASA I, who were undergoing inguinal hernia repair were enrolled after written informed consents were obtained from parents of all participants.

The results showed that the incidence of EA showed statistical significant reduction in dexemedetomedine group (15\%) than propofol group (20\%) and much reduction than saline group $(60 \%)$ with no difference in the discharge time, FLACC scale was clinically but not statistically lower in dexemedetomedine group than propofol group and much lower than saline group at all times with no significant difference in the number of patients administered fentanyl, Ramsay's sedation scale was clinically higher in dexemeditomedine group than propofol group and much higher than saline group at all times but without statistical difference, inspired sevoflurane concentration was statistically lower in dexemeditomedine group than the other two groups at all times except at T7, where it was reduced in both dexemeditomedine and propofol groups but the reduction was more in dexemeditomedine group and heart rate (HR) and mean arterial pressure (MAP) showed statistical significant reduction in dexemedetomedine group than the other two groups at all times compared to baseline value (T0) except at $\mathrm{T} 7$, where they were reduced in both dexemedetomedine and propofol groups. In dexemedetomedine group, eight cases $(40 \%)$ showed reduction in HR and four cases $(20 \%)$ showed reduction in MAP but only one case $(5 \%)$ required atropine and other one $(5 \%)$ required ephedrine while in propofol group, one case $(5 \%)$ showed reduction in HR and other case $(5 \%)$ showed reduction in MAP but did not require atropine or ephedrine respectively.

Key words: Children, Anesthesia, Dexemeditomedine, Propofol, Sevoflurane

\section{Introduction}

Sevoflurane is an inhalation anesthetic widely used in pediatric anesthesia with minimal airway irritation. However, the emergence agitation (EA), occurring after general anesthesia in children, is more frequent after using sevoflurane (Uezono et al, 2000).

First described in the early 1960 s, EA is a clinical condition in which children experience a variety of behavioral disturbances, including crying, sobbing, thrashing, and disorientation, during early emergence from anesthesia (Eckenhoff et al, 1961).

Various attempts have been made to reduce the problem of EA and delirium. Many drugs, including propofol, fentanyl, clonidine and dexmedetomidine, have been investigated to attenuate the incidence of EA and delirium (Lerman, 2007).

The current study was designed to evaluate the effect of dexemeditomedine and propofol on EA following sevoflurane anesthesia in children.

\section{Patients, Materials and Methods}

This study was approved by the local ethical committee. Written informed consents were obtained from parents of all participants. Sixty children, aged 4-6 years, ASA I, who were undergoing inguinal hernia repair were enrolled. Children with developmental delay, psychological or neurological disorders, articulation disorders, abnormal airway, reactive airway disease and history of epilepsy were excluded. All patients fasted at least 4 hours (hrs), with an opportunity to drink clear fluids up to 2 hrs before operation. 
The enrolled children were randomly allocated into one of three groups (20 patients each) to receive either dexemeditomedine (GI), propofol (GII), or saline (GIII). For GI, dexmedetomidine was mixed in normal saline to make $1 \mu \mathrm{g} / \mathrm{mL}$ in $50 \mathrm{~mL}$ syringe. For GIII, normal saline was also prepared in $50 \mathrm{~mL}$ syringe.

No premedication was given. Anesthesia was induced by inhalation of $8 \%$ sevoflurane in oxygen via a face mask at a gas flow of $4 \mathrm{~L} / \mathrm{min}$. The induction scale was assessed based upon mask acceptance; $1=$ accept mask readily; $2=$ slight fear of mask, easily calmed; $3=$ not calmed with reassurance; 4=terrified, crying, agitated (Weldon et al, 1992). A scale score of 1 or 2 was considered to be satisfactory induction. After loss of consciousness, intravenous access and laryngeal mask airway (LMA) of adequate size were inserted. Anesthesia was maintained by sevoflurane to maintain BIS score at 40-60 during surgery.

After LMA insertion, all children were received caudal block in the lateral position using $23 \mathrm{G}$ needle under sterile technique with $1 \mathrm{~mL} \mathrm{~kg}^{-1}$ of $0.2 \%$ levobupivacaine. Skin incision used as test of adequate analgesia of the caudal block, and the block was considered inadequate if heart rate increased $>20 \%$ within 60 seconds (sec) of skin incision and this child was excluded from the study and replaced by another one.

GI children were received dexemeditomedine $(1 \mu \mathrm{g} / \mathrm{kg})$ two minutes (min) after induction of anesthesia followed by 0.1 $\mu \mathrm{g} / \mathrm{kg} / \mathrm{hr}$ infusion until the end of surgery. GII children were received propofol $1 \mathrm{mg}$ $\mathrm{kg}^{-1} 5$ min before the end of anesthesia. GIII children were received saline infusion at the same rate of dexemeditomedine infusion started 2 min after induction of anesthesia till the end of surgery.
Spontaneous ventilation was maintained throughout the operation. After skin closure, sevoflurane and dexmedetomidine or saline administration were discontinued. Inspired sevoflurane concentration, MAP, and HR were recorded just after induction of anesthesia ( $\mathrm{T} 0=$ baseline), then 5,10 , 20, 30, 40, 50 min after induction of anesthesia (T1, T2, T3, T4, T5 and T6 respectively) and at the end of operation (T7). Atropine $0.01 \mathrm{mg} \mathrm{kg}^{-1}$ was given when the HR decreased $>20 \%$ of baseline value (T0). Hypotension (decreased MAP $>20 \%$ of baseline value) was treated by ephedrine $0.15 \mathrm{mg} \mathrm{kg}^{-1}$.

The LMA was removed when the patients opened their eyes spontaneously. When children were fully awake, and had stable vital signs, patent airway without support, and oxygen saturation $>95 \%$ on breathing room air, they were transferred to the postanesthesia care unit (PACU).

In the PACU, children were monitored for EA by the anesthetist at arrival and every $5 \mathrm{~min}$ for up to $30 \mathrm{~min}$ as most of the EA episodes occurred within 30 min of PACU arrival (Sato et al, 2010). EA was rated using a four-point scale modified by Watcha et al. $(1=$ calm, 2 = crying, but can be consoled, $3=$ crying and cannot be consoled, $4=$ agitated and thrashing around) (Watcha et al, 1992). If a child fell asleep, this was defined as a score of 0 . Children with scores of 3 or 4 were considered to have had an EA episode. Incidence of EA and discharge time in each group was recorded. Postoperative pain was assessed with the Face, Legs, Activity, Cry, Consolability scale (FLACC) (Voepel-lewis et al, 2010) upon PACU arrival, at 30,60 , and $120 \mathrm{~min}$ postoperatively. When FLACC scores $\geq 4$, fentanyl $(0.5 \mu \mathrm{g} / \mathrm{kg})$ was administered. Number of patients received postoperative fentanyl was recorded. 
Table 1: Face, Legs, Activity, Cry, Consolability (FLACC) scale.

\begin{tabular}{|c|c|c|c|}
\hline \multirow[t]{2}{*}{ Item } & \multicolumn{3}{|c|}{ Score } \\
\hline & 0 & 1 & 2 \\
\hline Face & $\begin{array}{l}\text { No particular expression or } \\
\text { smile. }\end{array}$ & $\begin{array}{l}\text { Occasional grimace, frown, withdrawn } \\
\text { or disinterested. }\end{array}$ & $\begin{array}{l}\text { Frequent to constant } \\
\text { frown, clenched jaw, quiver- } \\
\text { ing chin. }\end{array}$ \\
\hline Legs & Normal position or relaxed. & Uneasy, restless, or tense. & Kicking, or legs drawn up. \\
\hline Activity & $\begin{array}{l}\text { Lying quietly, normal posi- } \\
\text { tion, moves easily. }\end{array}$ & $\begin{array}{l}\text { Squirming, shifting back and forth, or } \\
\text { tense. }\end{array}$ & Arched, rigid, or jerking. \\
\hline Cry & No cry. & $\begin{array}{l}\text { Moans, whimpers, or occasional com- } \\
\text { plaint. }\end{array}$ & $\begin{array}{l}\text { Crying steadily, screams or } \\
\text { sobs, frequent complaints. }\end{array}$ \\
\hline $\begin{array}{l}\text { Conso- } \\
\text { lability }\end{array}$ & Content, relaxed. & $\begin{array}{l}\text { Reassured by occasional touching, hug- } \\
\text { ging, or being talked to; distractible }\end{array}$ & $\begin{array}{l}\text { Difficult to console or com- } \\
\text { fort. }\end{array}$ \\
\hline
\end{tabular}

Sedation level was assessed at PACU level, 30, $60 \& 120$ min postoperatively with Sedation scale; $1=$ anxious and agitated or restless, or both; $2=$ co-operative, oriented, and calm; $3=$ responsive to commands only; 4=exhibiting brisk response to light glabellar tap or loud auditory stimulus; $5=$ exhibiting a sluggish response to light glabellar tap or loud auditory stimulus; and 6=unresponsive (Ramsay et al, 1974). Ad- verse effects (airway obstruction, laryngospasm, nausea or vomiting and delayed voiding) were all recorded. Postoperative nausea or vomiting was treated with ondansetron $0.1 \mathrm{mg} \mathrm{kg}$. Nausea was defined as a feeling of the urge to vomit, and vomiting was defined as retching and any expulsion of liquid gastric contents after oral fluid intake. Patients received ondanosteron were recorded.

\section{Results}

The results are shown in tables $(2,3,4,5,6,7)$ and figures $(1,2)$.

Table 2: Demographic and anesthetic characteristics

\begin{tabular}{|l|l|l|l|l|}
\hline \multirow{2}{*}{$\begin{array}{l}\text { Demographic and anesthetic } \\
\text { characteristics }\end{array}$} & GI & GII & GIII & \multirow{2}{*}{ P-value } \\
\cline { 2 - 4 } & $\begin{array}{l}\text { Mean } \pm \text { SD or } \\
\text { Number (\%) }\end{array}$ & $\begin{array}{l}\text { Mean } \pm \text { SD } \\
\text { Number (\%) }\end{array}$ & $\begin{array}{l}\text { Mean } \pm \text { SD } \\
\text { Number (\%) }\end{array}$ & or \\
\hline Age (Years) & $4.8 \pm 0.8$ & $5.0 \pm 0.8$ & $4.9 \pm 0.7$ & 0.725 \\
\hline Weight (Kg) & $17.5 \pm 1.8$ & $17.8 \pm 1.8$ & $17.7 \pm 1.7$ & 0.894 \\
\hline Duration of anesthesia (min) & $45.5 \pm 6.9$ & $45.2 \pm 6.6$ & $45.3 \pm 6.7$ & 0.989 \\
\hline Satisfactory induction & $16(80 \%)$ & $15(75 \%)$ & $16(80 \%)$ & 0.842 \\
\hline
\end{tabular}

Table 3: Incidence of adverse effect.

\begin{tabular}{|l|l|l|l|l|}
\hline \multirow{3}{*}{ Incidence of adverse effects } & GI & GII & GIII & \\
\cline { 2 - 4 } & Number (\%) & Number (\%) & Number (\%) & P-value \\
\hline Airway obstruction & $1(5 \%)$ & $2(10 \%)$ & $1(5 \%)$ & 0.765 \\
\hline Laryngospasm & $0(0 \%)$ & $2(10 \%)$ & $1(5 \%)$ & 0.349 \\
\hline Nausea and vomiting & $1(5 \%)$ & $3(15 \%)$ & $1(5 \%)$ & 0.418 \\
\hline Ondanosteron use & $1(5 \%)$ & $3(15 \%)$ & $1(5 \%)$ & 0.418 \\
\hline Delayed voiding & $0(0 \%)$ & $0(0 \%)$ & $0(0 \%)$ & 1.000 \\
\hline
\end{tabular}

Table 4: Agitation score, incidence of emergence agitation and discharge time.

\begin{tabular}{|c|c|c|c|c|c|c|c|c|c|c|}
\hline \multirow[b]{2}{*}{ Agitation score } & \multicolumn{3}{|l|}{ GI } & \multicolumn{3}{|l|}{ GII } & \multicolumn{3}{|l|}{ GIII } & \multirow[b]{2}{*}{ P-value } \\
\hline & $\begin{array}{l}\text { Range or } \\
\mathrm{M} \pm \mathrm{SD}\end{array}$ & $\begin{array}{l}\text { Median or } \\
\text { No. }(\%)\end{array}$ & $\begin{array}{c}\text { Mean } \\
\text { rank }\end{array}$ & $\begin{array}{l}\text { Range or } \\
\mathrm{M} \pm \mathrm{SD}\end{array}$ & $\begin{array}{l}\text { Median or } \\
\text { No. }(\%)\end{array}$ & $\begin{array}{l}\text { Mean } \\
\text { rank }\end{array}$ & $\begin{array}{l}\text { Range or } \\
\mathrm{M} \pm \mathrm{SD}\end{array}$ & $\begin{array}{l}\text { Median or } \\
\text { No. }(\%)\end{array}$ & $\begin{array}{l}\text { Mean } \\
\text { Rank }\end{array}$ & \\
\hline At PACU arrival & $0-2$ & 0.0 & 24.3 & $0-3$ & 0.0 & 31.4 & $0-4$ & 0.5 & 35.8 & 0.054 \\
\hline At $5 \mathrm{~min}$ & $0-2$ & 0.0 & 22.5 & $0-3$ & 1.0 & 29.3 & $0-4$ & 1.5 & 39.6 & $0.005^{*}$ \\
\hline At $10 \mathrm{~min}$ & $0-3$ & 2.0 & 27.3 & $0-3$ & 2.0 & 28.9 & $0-4$ & 2.0 & 35.3 & 0.276 \\
\hline At $15 \mathrm{~min}$ & $0-3$ & 1.0 & 22.2 & $0-3$ & 2.0 & 30.9 & $0-3$ & 2.5 & 38.4 & $0.010^{*}$ \\
\hline At $20 \mathrm{~min}$ & $0-3$ & 1.0 & 23.8 & $1-2$ & 1.0 & 26.8 & $1-3$ & 2.0 & 41.0 & $<0.001^{*}$ \\
\hline At $25 \mathrm{~m}$ in & $1-2$ & 1.0 & 29.5 & $1-2$ & 1.0 & 29.5 & $1-2$ & 1.0 & 32.5 & 0.758 \\
\hline At $30 \mathrm{~min}$ & $1-2$ & 1.0 & 28.5 & $1-2$ & 1.0 & 30.0 & $1-2$ & 1.0 & 33.0 & 0.438 \\
\hline $\begin{array}{l}\text { Agitation inci- } \\
\text { dence }\end{array}$ & \multicolumn{3}{|l|}{$3(15 \%)$} & \multicolumn{3}{|l|}{$4(20 \%)$} & \multicolumn{3}{|l|}{$12(60 \%)$} & $0.004 *$ \\
\hline Discharge time & \multicolumn{3}{|c|}{$229.8 \pm 35.2$} & \multicolumn{3}{|l|}{$235 \pm 38.9$} & \multicolumn{3}{|c|}{$240.5 \pm 44.7$} & 0.698 \\
\hline
\end{tabular}


Table 5: FLACC scale and number of patients administered fentanyl.

\begin{tabular}{|c|c|c|c|c|c|c|c|c|c|c|}
\hline \multirow[b]{2}{*}{ FLACC Scale } & \multicolumn{3}{|c|}{ GI } & \multicolumn{3}{|c|}{ GII } & \multicolumn{3}{|c|}{ GIII } & \multirow[b]{2}{*}{$\begin{array}{c}\text { P- } \\
\text { value }\end{array}$} \\
\hline & $\begin{array}{l}\text { Range or } \\
\text { No. }(\%)\end{array}$ & Median & $\begin{array}{r}\text { Mean } \\
\text { Rank }\end{array}$ & $\begin{array}{l}\text { Range or } \\
\text { No. (\%) }\end{array}$ & Median & $\begin{array}{l}\text { Mean } \\
\text { Rank }\end{array}$ & $\begin{array}{c}\text { Range or } \\
\text { No. (\%) }\end{array}$ & Median & $\begin{array}{l}\text { Mean } \\
\text { Rank }\end{array}$ & \\
\hline At PACU arrival & $0-5$ & 0.0 & 25.9 & $0-6$ & 1.0 & 32.5 & $0-6$ & 1.0 & 33.0 & 0.587 \\
\hline At $30 \mathrm{~min}$ & $0-5$ & 0.0 & 28.0 & $0-6$ & 0.5 & 30.2 & $0-7$ & 1.0 & 33.3 & 0.738 \\
\hline At $60 \mathrm{~min}$ & $0-6$ & 1.0 & 29.7 & $0-6$ & 1.0 & 30.8 & $0-8$ & 1.0 & 31.0 & 0.989 \\
\hline At $120 \mathrm{~min}$ & $0-6$ & 0.0 & 29.7 & $0-7$ & 0.5 & 30.2 & $0-7$ & 1.0 & 31.6 & 0.957 \\
\hline $\begin{array}{l}\text { No. of patients } \\
\text { given fentanyl }\end{array}$ & \multicolumn{3}{|c|}{$9(45 \%)$} & \multicolumn{3}{|c|}{$8(40 \%)$} & \multicolumn{3}{|c|}{$10(50 \%)$} & 0.817 \\
\hline
\end{tabular}

Table 6: Ramsay's sedation scale.

\begin{tabular}{|c|c|c|c|c|c|c|c|c|c|c|}
\hline \multirow[b]{2}{*}{$\begin{array}{l}\text { Ramsay's seda- } \\
\text { tion scale }\end{array}$} & \multicolumn{3}{|c|}{ GI } & \multicolumn{3}{|c|}{ GII } & \multicolumn{3}{|c|}{ GIII } & \multirow[b]{2}{*}{ Pvalue } \\
\hline & Range & Median & $\begin{array}{l}\text { Mean } \\
\text { Rank }\end{array}$ & Range & Median & $\begin{array}{l}\text { Mean } \\
\text { rank }\end{array}$ & Range & Median & $\begin{array}{l}\text { Mean } \\
\text { rank }\end{array}$ & \\
\hline At PACU arrival & $1-$ & 5.0 & 36.5 & $1-6$ & 4 & 30.6 & $1-6$ & 3.0 & 24.4 & 0.083 \\
\hline At $30 \mathrm{~min}$ & $1-5$ & 2.0 & 35.9 & $1-4$ & 2.0 & 32.1 & $1-3$ & 2.0 & 23.5 & 0.056 \\
\hline At $60 \mathrm{~min}$ & $1-5$ & 2.0 & 37.3 & $1-4$ & 2.0 & 29.3 & $1-3$ & 2.0 & 24.9 & 0.056 \\
\hline At $120 \mathrm{~min}$ & $1-3$ & 3.0 & 32.2 & $1-3$ & 3.0 & 30.1 & $1-3$ & 2.0 & 29.2 & 0.834 \\
\hline
\end{tabular}

Table 7: Inspired sevoflurane concentration.

\begin{tabular}{|c|c|c|c|c|c|c|c|c|c|c|}
\hline \multirow{2}{*}{$\begin{array}{l}\text { Inspired } \\
\text { sevoflurane } \\
\text { concentration }\end{array}$} & \multicolumn{3}{|c|}{ GI } & \multicolumn{3}{|c|}{ GII } & \multicolumn{3}{|c|}{ GIII } & \multirow[t]{2}{*}{ P-value } \\
\hline & Range & Median & $\begin{array}{l}\text { Mean } \\
\text { Rank }\end{array}$ & Range & Median & $\begin{array}{l}\text { Mean } \\
\text { Rank }\end{array}$ & Range & Median & $\begin{array}{c}\text { Mean } \\
\text { rank }\end{array}$ & \\
\hline At T0 & $2-2$ & 2 & 30.5 & $2-2$ & 2.0 & 30.5 & $2-2$ & 2.0 & 30.5 & 1.000 \\
\hline At T1 & $1.6-1.9$ & 1.8 & 10.5 & $2-2$ & 2.0 & 40.5 & $2-2$ & 2.0 & 40.5 & $<0.001 *$ \\
\hline At T2 & $1.3-1.8$ & 1.6 & 10.5 & $2-2$ & 2.0 & 40.5 & $2-2$ & 2.0 & 40.5 & $<0.001 *$ \\
\hline At T3 & $1.2-1.6$ & 1.4 & 10.5 & $2-2$ & 2.0 & 40.5 & $2-2$ & 2.0 & 40.5 & $<0.001 *$ \\
\hline At T4 & $0.8-1.1$ & 1.0 & 10.5 & $2-2$ & 2.0 & 40.5 & $2-2$ & 2.0 & 40.5 & $<0.001 *$ \\
\hline At T5 & $0.8-1.6$ & 1.1 & 10.5 & $2-2$ & 2.0 & 40.5 & $2-2$ & 2.0 & 40.5 & $<<0.001^{*}$ \\
\hline At T6 & $0.7-1.1$ & 1.0 & 10.5 & $2-2$ & 2.0 & 40.5 & $2-2$ & 2.0 & 40.5 & $0.001 *$ \\
\hline At T7 & $0.7-1.1$ & 1.0 & 10.5 & $1.5-2$ & 1.7 & 32.0 & $2-2$ & 2.0 & 49.0 & $<0.001 *$ \\
\hline
\end{tabular}

\section{Discussion}

In the present study, the demographic, anesthetic characteristics and incidence of adverse effects showed no significant differences. The agitation score was statistically significantly lower in GI than GII and much lower than GIII at 5, 15 and 20 min, but at PACU arrival, at 10, 25 and 30 min, it was clinically but not statistically lower in GI than GII and lowest than GIII. The incidence of EA showed statistical significant reduction in GI (15\%) than GII $(20 \%)$ and much reduction than GIII $(60 \%)$. Discharge time was not statistically different among three groups.

FLACC scale showed clinical but not statistical reduction in GI than GII and much reduction than group III at all times, without statistical difference among groups in patients administered fentanyl. With re- spect to Ramsay sedation scale, it was clinically higher in GI than GII and much higher than GIII at all times but without statistical difference (Ye et al, 2014).

Regarding inspired sevoflurane concentration, there was statistical significant reduction in GI than the other two Gs at all times except at T7, where it was reduced in both GI and II but the reduction was more in GI.

As regard HR and MAP, there were statistical significant reduction in GI than the other two Gs at all times compared to baseline value (T0) except at $\mathrm{T} 7$, where they were reduced in both group I and II. In GI, eight cases (40\%) showed reduction in HR and four cases (20\%) showed reduction in MAP but only one case $(5 \%)$ required atropine and other one $(5 \%)$ required ephedrine while in GII, only one 


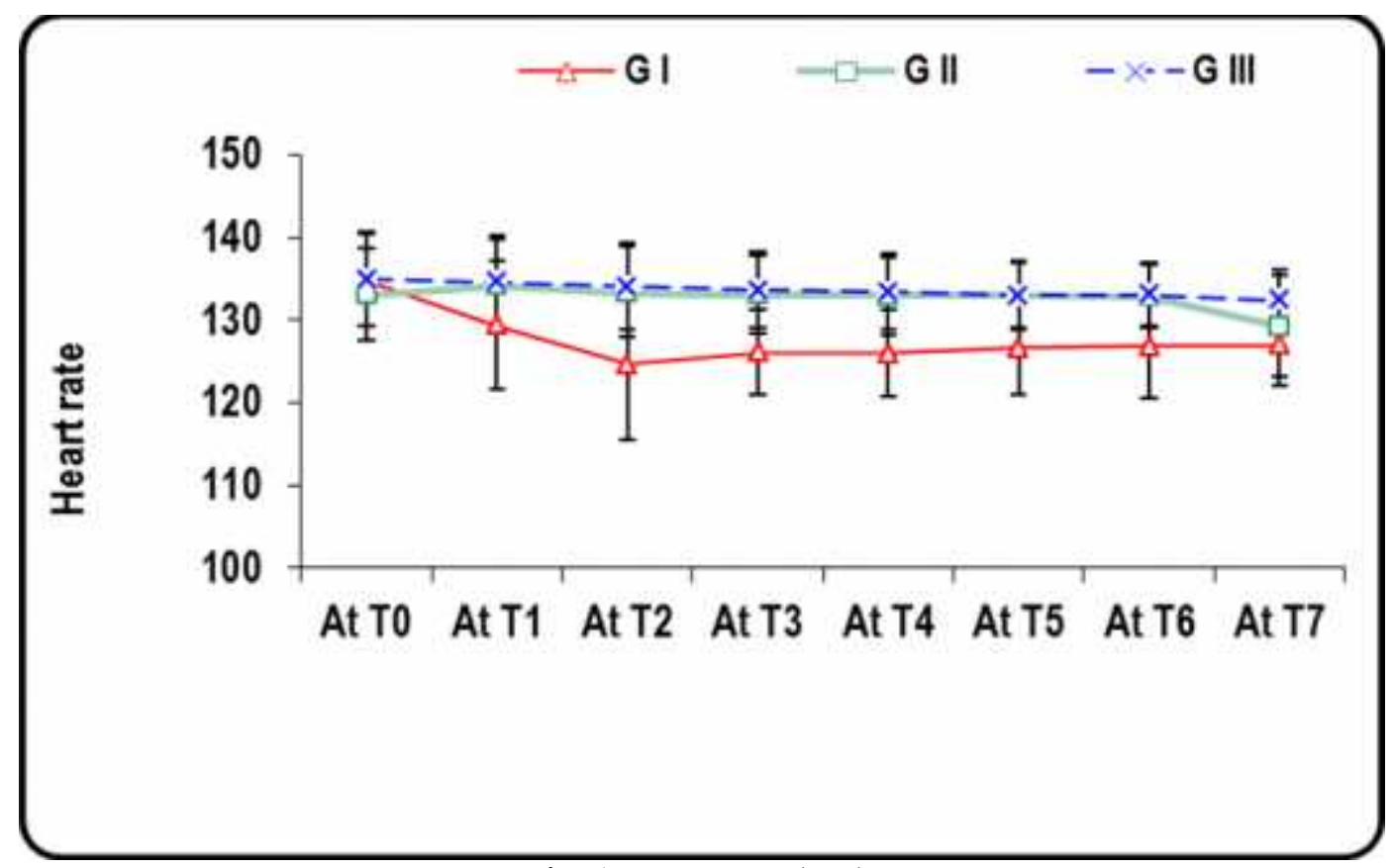

Fig. 1: Heart rate (HR).

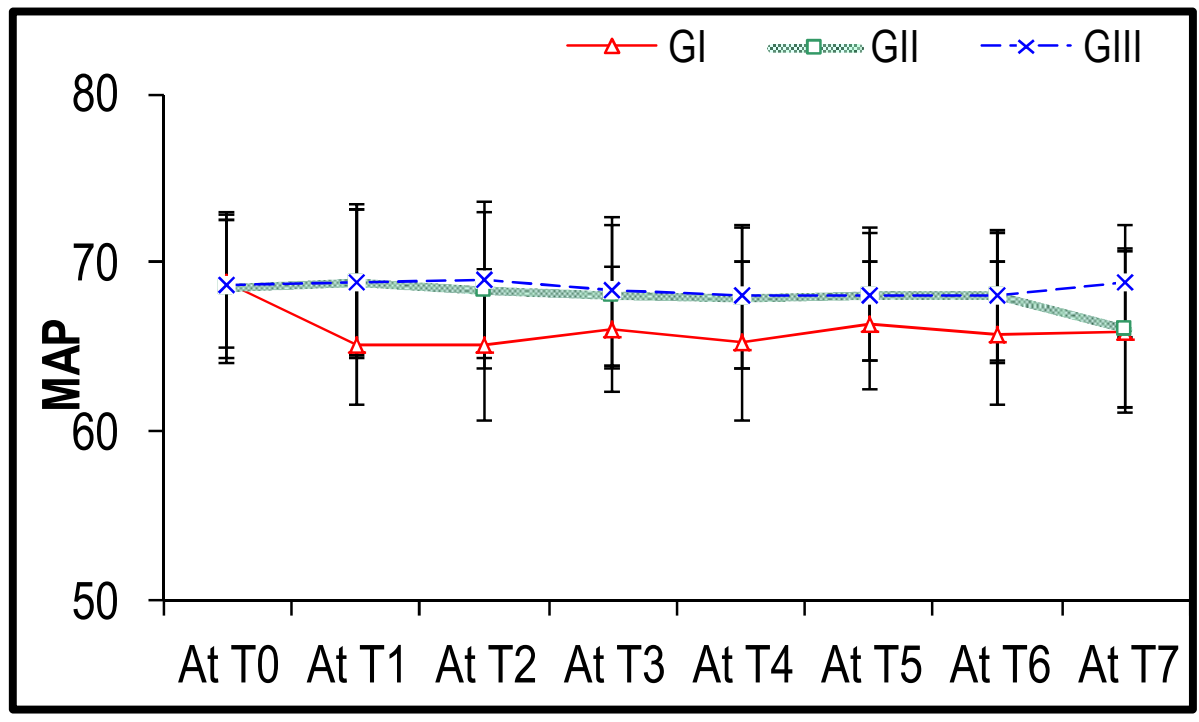

Fig. 2: Mean arterial pressure (MAP), and patients showing hypotension.

case $(5 \%)$ showed reduction in HR and other case (5\%) showed reduction in MAP, but did not require atropine or ephedrine respectively.

EA is not a new phenomenon, though its prevalence has increased with the introduction of sevoflurane, especially in preschool aged children. EA is self-limiting and resolves spontaneously, but restless recoveries can result in patient injury, surgical site damage and dissatisfaction for patients and parents. This characteristic of EA has been attributed to several factors such as patient-related (age, anxiety, and temperament), anesthesia-related (rapid emergence, and anesthetics), and surgeryrelated (pain and surgery type) (Cravero et $a l, 2000)$. In the current study, several possible factors of EA were excluded such as preoperative anxiety, surgical type, and postoperative pain. The EA incidence was up to $70 \%$ in sevoflurane anesthesia 
(Gulter et al, 2005), but frequent EA after sevoflurane was not clearly understood. A meta-analysis showed that propofol, fentanyl, $\alpha_{2}$-adrenergic receptor agonist, and ketamine have a prophylactic effect (Dahmani et al, 2010).

The present study showed that agitation score was significantly lower in dexemeditomedine group than propofol group and much lower than saline group at $5,15 \&$ $20 \mathrm{~min}$, but at PACU arrival, at 10, $25 \&$ $30 \mathrm{~min}$, it was clinically but not statistically lower in dexemeditomedine group than propofol group and much lower than saline group.

The current study showed that EA incidence was significantly lower in dexemeditomedine group than propofol group and much lower than saline group. This result was matched with Kim et al. (2014) who reported that dexmedetomidine administration reduced EA significantly without delaying discharge.

The reason for reducing EA is yet unclear; however, the analgesic and sedative effects of dexmedetomidine may provide a protective effect against EA (Patel et al, 2010). A study also suggested that lower incidence of EA could be related to the lower concentration of sevoflurane ( $\mathrm{Na}$ et al, 2013).This agreed with Kim et al. (2013) who showed that the use of either propofol or fentanyl at the discontinuation of sevoflurane anesthesia effectively reduced the incidence of EA, and propofol might be preferable regarding the lower incidence of vomiting and matched with Chen et al. (2010) who observed that propofol or midazolam in combination with fentanyl were both effective in reducing EA compared to ketamine in children underwent cataract surgery. This also agreed with Kim et al. (2011) who found that propofol and midazolam decreased the incidence of EA by about $40 \%$ in patients undergoing strabismus surgery.

Propofol delays or modifies emergence and decreases emergence agitation depend- ing on the time of administration. Being a short acting medication, propofol given at induction could not prevent emergence agitation (Abu-Shahwan, 2008).

The present study showed that pain score was clinically lower in dexemeditomedine group than propofol group and lowest than saline group. This was matched with Kim et al. (2014) who observed lower pain score in patients received dexemeditomedine in comparison to those received saline.

The current study showed high sedation score in patients received dexemeditomedine compared to those received propofol and higher than those received saline. This was matched with Kim et al. (2014) who reported that sedation score was higher in patients received dexemeditomedine compared to those received placebo.

The present study showed statistical significant reduction of the inspired sevoflurane concentration in dexemeditomedine group than other groups at all times except at the end of anesthesia, where it was reduced in both dexemeditomedine and propofol groups but reduction was more in dexemeditomedine group. This agreed with Kim et al. (2014) who observed that ET-sevo was significantly lower in dexemeditomedine group than in saline group and reduced by $(60 \% \pm 10 \%)$ in dexemeditomedine group compared to saline group. In several studies performed on adults undergoing abdominal surgery, ET-sevo was decreased by $27.3-33 \%$ with a dexmedetomidine $1 \mu \mathrm{g} / \mathrm{kg}$ bolus and $0.4-0.6$ $\mu \mathrm{g} / \mathrm{kg} / \mathrm{h}$ infusion (Ohtani et al, 2008). In children undergoing tonsillectomy, the ETsevo was reduced up to $41.6 \%$ with the dexmedetomidine $2 \mu \mathrm{g} / \mathrm{kg}$ bolus, followed by $0.7 \mu \mathrm{g} / \mathrm{kg} / \mathrm{h}$ infusion when compared with intraoperative fentanyl bolus (Patel et al, 2010).

The current study showed significant reduction in HR and MAP in dexemeditomedine group than other groups at all times compared to baseline value except at 
the end of anesthesia, where it showed reduction in HR and MAP in both dexemeditomedine and propofol groups but the reduction was more in dexemeditomedine group. In dexemeditomedine group, eight cases showed reduction in HR and four cases showed reduction in MAP but one case $(5 \%)$ required atropine and other one $(5 \%)$ required ephedrine while in propofol group, only one case $(5 \%)$ showed reduction in HR and other one (5\%) showed reduction in MAP, but did not require atropine or ephedrine respectively. This agreed with Kim et al. (2014) who found that MAP and HR were significantly lower in dexmedetomidine group than in saline group; MAP and HR decreased by $22-28 \%$ and $18-21 \%$ respectively in dexmedetomidine group than saline group. Atropine was given to 6 patients of dexmedetomidine group who showed bradycardia with or without hypotension ( $p=0.020)$, during the dexmedetomidine load. The most common hemodynamic effects of dexmedetomidine are bradycardia and hypotension, which are attributed to central $\alpha_{2}$-agonist properties. Transient hypertension can also be result from peripheral $\alpha$-receptor stimulation (Su and Hammer, 2011).

\section{Conclusion}

The outcome results proved that the intraoperative dexemedetomedine infusion $(1 \mu \mathrm{g} / \mathrm{kg}$ bolus, followed by $0.1 \mu \mathrm{g} / \mathrm{kg} / \mathrm{h}$ infusion) after sevoflurane anesthesia was superior to both single dose propofol (1 $\mathrm{mg} \mathrm{kg} 5 \mathrm{~min}$ before the end of anesthesia) and saline infusion (control) because it decrease the agitation score, the incidence of EA and pain score without delaying discharge or increasing adverse effect, made the patients more comfort by making the patients sedated, decrease sevoflurane requirement without but must be used with caution to avoid hypotension and bradycardia.

\section{References}

Abu-Shahwan I, 2008: Effect of propofol on emergence behavior in children after sevoflu- rane general anesthesia. Pediatr. Anesth. 18: 55-9.

Chen, J, Li, W, Hu, X, Wang, D, 2010: Emergence agitation after cataract surgery in children: a comparison of midazolam, propofol and ketamine. Pediatr Anesth. 20:873-9.

Cravero, J, Surgenor, S, Whalen, K, 2000: Emergence agitation in pediatric patients after sevoflurane anesthesia and no surgery: a comparison with halothane. Pediatr Anesth. 10: 419-24.

Dahmani, S, Stany, I, Brasher. C, et al, 2010: Pharmacological prevention of sevoflurane- and desflurane-related emergence agitation in children: a meta-analysis of published studies. Br. J. Anesth. 104:216-23.

Eckenhoff, JE, Kneale, DH, Dripps, RD, 1961: The incidence and etiology of post-anesthetic excitement. Anesthesiol. 22:667-73.

Guler, G, Akin, A, Tosun, Z, Ors, S, Esmaoglu, A, et al, 2005: Single dose dexmedetomidine reduces agitation and provides smooth extubation after pediatric adenotonsillectomy. Pediatr Anesth. 15:762-6.

Kim, MS, Moon, BE, Kim, H, Lee JR, 2013: Comparison of popofol and fentanyl administered at the end of anesthesia for prevention of emergence agitation after sevoflurane anesthesia in children. Br. J. Anesth. 110, 2:274-80.

Kim, NY, Kim, SY, Yoon, HJ, Kim, H, 2014: Effect of dexmedetomidine on sevoflurane requirements and emergence agitation in children undergoing ambulatory surgery. onsei Med J. 55, 1:209-15.

Kim, YH, Yoon, SZ, Lim, HJ, Yoon, SM, 2011: Prophylactic use of midazolam or propofol at the end of surgery may reduce the incidence of emergence agitation after sevoflurane anaesthesia. Anaesth. I. C. 39:904-8.

Lerman, J, 2007: Inhalation agents in pediatric anesthesia - an update. Curr Opin Anesthesiol. 20:221-6.

Na, HS, Song, IA, Hwang, JW, Do, SH, Oh, AY, 2013: Emergence agitation in children undergoing adenotonsillectomy: a comparison of sevoflurane vs. sevoflurane-remifentanil administration. Acta Anaesthesiol. Scand. 57: 100-5.

Ohtani, N, Kida, K, Shoji, K, Yasui, Y, Masaki, E, 2008: Recovery profiles from dexmedetomidine as a general anesthetic adjuvant in patients undergoing lower abdominal surgery. Anesth Analg. 107:1871-4. 
Patel, A, Davidson, M, Tran, MC, Quraishi, H, Schoenberg, C, et al, 2010: Dexmedetomidine infusion for analgesia and prevention of emergence agitation in children with obstructive sleep apnea syndrome undergoing tonsillectomy and adenoidectomy. Anesth Analg. 111:1004-10.

Ramsay, MA, Savege, TM, Simpson, BR, Goodwin, R, 1974: Controlled sedation with alphaxalone-alphadolone. Br. Med. J. 2:656-9.

Sato, M, Shirakami, G, Nishimura, M, Matsuura, S, Tanimoto, K, et al, 2010: Effect of single-dose dexmedetomidine on emergence agitation and recovery profiles after sevoflurane anesthesia in pediatric ambulatory surgery. J. Anesth. 24:675-82.

Su, F, Hammer, GB, 2011: Dexmedetomidine: pediatric pharmacology, clinical uses and safety. Expert. Opin. Drug Saf. 10:55-66.
Uezono, S, Goto, T, Terui, K, Ichinose, F, Ishguro, Y, et al, 2000: Emergence agitation after sevoflurane versus propofol in pediatric patients. Anesth. Analg. 91:563-6.

Voepel-Lewis, T, Zanotti, J, Dammeyer, JA, Merkel, S, 2010: Reliability and validity of the face, legs, activity, cry, consolability behavioral tool in assessing acute pain in critically ill patients. Am. J. Crit/ Care 19:55-61.

Watcha, MF, Ramirez-Ruiz, M, White, PF, Jones, MB, Lagueruela, RG, et al, 1992: Perioperative effects of oral ketorolac and acetaminophen in children undergoing bilateral myringotomy. Canad. J. Anesth. 39:649-54.

Weldon, BC, Watcha, MF, White, PF, 1992: Oral midazolam in children: effect of time and adjunctive therapy. Anesth. Analg. 75:51-55. Ye, W, Hu, Z, Sun, C, 2014: Application of dezoxine plus dexmedetomidine in strabismus surgery. Zhon. Yi Xue Za Zhi. 94, 19:1479-82. 